\title{
Association of Il-6 and Il-10 Genes Polymorphisms with Breast Cancer in Egyptian Women
}

\author{
Abdelnaser Badawy ${ }^{1}$, Hussein Abdelaziz Abdalla ${ }^{1}$, Sabry A. \\ Mahmoud $^{2}$, Saad Elshafei ${ }^{3}$ \& Dina A. Eltantawy ${ }^{4}$ \\ Medical Biochemistry ${ }^{1}$ General Surgery ${ }^{2,}$ Histology ${ }^{3} \&$ Pathology ${ }^{4}$ \\ Departments, Faculty of Medicine, Mansoura University, Egypt
}

\begin{abstract}
Cytokines are factors that are known to have both tumor-promoting and inhibitory effects on breast cancer growth depending on their relative concentrations and the presence of other modulating factors. Genetic polymorphisms of cytokine-encoding genes are known to predispose to malignant disease. Interleukins -10 and -6 are crucially involved in breast carcinogenesis. The aim of this study is to evaluate the role of IL-6 and IL-10 genes polymorphisms in the pathogenesis of breast cancer in a case - control study of 80 females with breast cancer and 80 healthy females as controls. Patients and controls underwent a clinical examination and finally, one $\mathrm{ml}$ blood samples were withdrawn from all cases into tubes containing EDTA as an anticoagulant for analysis of IL-6 and IL-10 genotypes. There were significant association between $C$ allele of the $G-174 \quad C$ promoter single nucleotide polymorphism $(S N P)$ in the IL-6 gene and breast cancer $(p=0.02)$. But, there were no significant difference in IL-10 1082G $\rightarrow$ A genotypes frequency in breast cancer when compared with normal individuals $(p=0.99)$. It's concluded that the CC genotype and $C$ allele of the $G-174 C$ in the IL-6 gene were associated with breast cancer in Egyptian women.
\end{abstract}

Key words: Cytokines, IL6, IL10, Gene polymorphism, Breast cancer

\section{INTRODUCTION}

Breast cancer is the most common malignancy threatening the health and life of women and its incidence has increased in both developed and developing countries ${ }^{1}$. Biologic mechanisms leading to the development of breast cancer are not clearly understood, but the role of cytokines in cancer immunity and carcinogenesis has been well established ${ }^{2}$.

Cytokine involved in different physiologic and pathophysiologic processes such as inflammation, bone metabolism, synthesis of C-reactive protein, and carcinogenesis ${ }^{3}$. IL-6 has also been shown to inhibit the growth of various breast cancer cell lines ${ }^{4}$, shows antiadhesive effects ${ }^{5}$, and modulates the estrogen and progesterone receptors content of these cells ${ }^{6}$. IL- 6 is thought to increase the activity of the 17-hydroxysteroid dehydrogenase, which converts estrone to estradiol, a process that may contribute to the increased concentration of estrogen around breast tumors. Furthermore, IL-6 has 
been shown to be involved in intercellular signaling between mesenchyme and breast cancer epithelium. These findings from in vitro studies extend to human breast cancer as elevated serum IL-6 levels were found to be independent prognosticators ${ }^{7,8}$.

The human IL-6 gene (IL6) is mapped to chromosome 7p21-24 with an upstream promoter containing 303 $\mathrm{bp}^{9}$. The common 174 G/C IL6 polymorphism has also been shown to influence in vivo protein expression by reducing transcription rates ${ }^{10}$.

The data on the 174 G/C IL6 polymorphism in breast cancer are controversial $^{11}$ reported that the presence of the IL6 polymorphism was associated with an improved outcome in high-risk breast cancer, whereas $^{12}$ showed that the IL6 polymorphism was predictive of an aggressive breast cancer phenotype.

As a multifunctional Th2cytokine with both immunosuppressive and antiangiogenic functions, interleukin10 (IL-10) may have both tumorpromoting and tumor-inhibiting properties $^{13}$. Other data suggest that polymorphic variations in the promoter sequences of IL-10 gene may influence the gene expression ${ }^{14}$ and consequently play a certain role in susceptibility and clinical course of breast cancer.

IL-10 is an important immunoregulatory cytokine mainly produced by activated $\mathrm{T}$ cells, monocytes, B cells and thymocytes. As an immune response modulator, IL-10 can both stimulate and suppress the immune response ${ }^{15}$. Numerous studies have shown that IL-10 may be involved in the pathogenesis of cancer, but the results were inconsistent. On one hand, increased serum IL-10 levels could facilitate development of cancer by suppressing expression of MHC class I and II antigens $^{\mathbf{1 6}}$ and preventing tumor antigen presentation to CD8-cytotoxic $\mathrm{T}$ lymphocytes. On the other hand, antiangiogenic effects of IL-10 are supposed to play a protective and preventive role against tumor. The gene encoding IL-10 is located on human chromosome 1q31-1q32, and is composed of five exons and four introns ${ }^{17}$.

Although several studies have shown the possible involvement of IL10 in the pathogenesis of breast cancer, as well as its association with prognosis in different ethnic populations, the results were not all consistent $^{18}$. Furthermore, little is known about the effect of these polymorphisms on the risk of beast cancer in the Egyptian population. The goal of this study was to evaluate whether IL-6 and IL-10 gene polymorphisms were associated with breast cancer in Egyptian women.

\section{SUBJECTS \& METHODS}

The present study included 80 women attended General Surgery Department, Mansoura University Hospital as breast cancer cases. After histopathologic diagnosis (FNAC, Trucut or Frozen section), the patients were subjected for either breast conservative surgery with axillary dissection or modified radical mastectomy depending upon tumor size and nuclear grading. Clinical tumor staging, lymph node 
involvement status, tumor size and demographic information including ages of menarche and menopause were derived from their charts, estrogen and progesterone receptors staining by immunohistochemistry. Also, 80 women who were clinically free from any malignancy or breast masses and age matched with cases were served as a control group, this group was selected from women attended General Surgery Departments, Mansoura University Hospital to undergo minor surgical operations unrelated to Oncology or Endocrinology. Written informed consents from patients and controls were obtained

Methods:

1-DNA extraction, PCR for IL-6$\left.{ }^{174} \mathrm{G} \rightarrow \mathrm{A}\right)$ and $\left(\mathrm{IL}-10^{1082} \mathrm{G} \rightarrow \mathrm{A}\right)$ polymorphisms:

One $\mathrm{mL}$ venous blood samples were collected from each subject in a polyethylene tubes containing EDTA as an anticoagulant and stored at- $30^{\circ}$ $\mathrm{C}$ until the subsequent use for DNA isolation and utilization for detection of $\mathrm{IL}-6^{-174} \mathrm{G} \rightarrow \mathrm{A}$ and $\mathrm{IL}-10^{1082} \mathrm{G} \rightarrow \mathrm{A}$ polymorphisms. Genomic DNA was extracted from peripheral blood using E.Z.N.A. Blood DNA Kits (purchased from Omega Bio-Tek,Inc., USA). (IL$\left.6^{-174} \mathrm{G} \rightarrow \mathrm{C}\right)$ and (IL-10 $\left.0^{-1082} \mathrm{G} \rightarrow \mathrm{A}\right)$ genes polymorphism were analyzed using a multiplex allele specific PCR amplification. Each PCR was performed with $300 \mathrm{ng}$ of DNA, 200 $\mathrm{mmol} / \mathrm{L}$ of each dNTP, $500 \mathrm{nmol} / \mathrm{L}$ of each primer and 2.5 units of Taq DNA polymerase (Amplitaq gold, Perkin Elmer cetus, Norwalk, Conn, USA). For evaluation of IL- $6^{-174} \mathrm{G} \rightarrow \mathrm{C}$ polymorphism, the polymorphic site was amplified with primers: Forward
(F) (5'-GAGCTTCTCTTTCGTTCC-

3'), Reverse (R1) (5'-
CCCTAGTTGTGTCTTGCC3')

specific for $G$ or Reverse (R2) (5'CCCTAGTTGTGTCTTGCG3')

specific for $\mathrm{C}^{\mathbf{1 9}}$. For PCR, the following procedure was used: 30 cycles were performed as follows; 94 ${ }^{\circ} \mathrm{C}$ for 30 seconds, $54{ }^{\circ} \mathrm{C}$ for 60 seconds and $72{ }^{\circ} \mathrm{C}$ for 60 seconds. The PCR amplification was completed by a final extension at $72{ }^{\circ} \mathrm{C}$ for 7 minutes. The amplification yields a product $234 \mathrm{bp}$. when electrophoresed on $3 \%$ agarose and stained with ethidium bromide, and visualized under UV light. For evaluation of IL$10^{-1082} \mathrm{G} \rightarrow \mathrm{A}$ polymorphism, the polymorphic site was amplified with primers: Forward (F) (5'AGCAACACTCCTCGTCGCAAC-

3'), Reverse (R1) (5'-
CCTATCCCTACTTCCCCC-3')

specific for $G$ or Reverse (R2) (5'CCTATCCCTACTTCCCCT-3')

specific for $\mathrm{A}^{\mathbf{2 0}}$. For PCR, the following procedure was used: 30 cycles of $94{ }^{\circ} \mathrm{C}$ for 30 seconds, $60{ }^{\circ} \mathrm{C}$ for 60 seconds and $72{ }^{\circ} \mathrm{C}$ for 60 seconds. The PCR amplification was completed by a final extension at 72 ${ }^{\circ} \mathrm{C}$ for 6 minutes. The amplification yields a product 179 bp when electrophoresed on $3 \%$ agarose and stained with ethidium bromide, and visualized under UV light. (Fig 1 \& 2)

\section{2- Immunohistochemistry of Estrogen \& progesterone Receptors:}

It is performed by using the avidin biotin complex utilizing DAB as chromogen. (Dako Denmark A/S, Produktionsvej 42, DK-2600 Glostrup, Denmark) (Fig $3 \& 4$ ). 
Primary Antibodies: (Purchased from Dako Denmark A/S, Denmark). DAKO Monoclonal Mouse AntiHuman Estrogen Receptor, Clone 1D5 (Anti-ER, 1D5) is intended to identify an epitope located on the N-terminal domain of the estrogen receptor. DAKO Monoclonal Mouse AntiHuman Progesterone Receptor, clone PgR 636 (Anti-PR, PgR 636) is intended for the detection of progesterone receptor. Standard immunoperoxidase kits (DAKOLSAB ${ }^{\circledR}$ kits) were supplied by Dako Denmark A/S (Denmark). The staining procedure was performed after Kiernan ${ }^{21}$ and the instructions of kit's manufacturers. Brown deposits at sites of specific receptors (antigens) indicated a positive reaction.

\section{Statistical analysis:}

Data were analyzed using SPSS statistical package version 17. Variables were presented as number and percent. Chi square test was used for comparison between groups. Student t-test was used for quantitative data (mean $\pm \mathrm{SD}$ ) to compare any variable against control group. $\quad \mathrm{P} \leq 0.05$ was considered statistically significant.

\section{RESULTS}

The demographics of cases and control enrolled in this study regarding age of menarche and menopausal status in both groups, Also, tumor characters including ER and PR expression, $\mathrm{LN}$ involvement, and tumor size and grade are summarized in Table (1). There were statistically significant decrease in the age of menarche in the patients with breast cancer when compared with normal individuals but no significant difference in menopausal status between the studied groups ( $p$ $=0.02, \mathrm{p}>0.05$ respectively).

The result of PCR determination of IL- $6^{-174} \mathrm{G} \rightarrow \mathrm{C}$ genotypes in the studied groups, shown in table (2), revealed significant association in $\mathrm{CC}$ genotype frequency in patients with breast cancer when compared with normal individuals $(\mathrm{p}=0.01)$. Also, there were significant association in $\mathrm{C}$ allele frequency in patients with breast cancer when compared with normal individuals $(\mathrm{p}=0.01)$.

The Analysis of association between IL- $6^{-174} \mathrm{G} \rightarrow \mathrm{C}$ genotypes and clinicopathological features of breast cancer patients, presented in Table (3), revealed no association between IL- $6^{-174} \mathrm{G} \rightarrow \mathrm{C}$ genotypes and ER expression, PR expression, tumor size, and grade of the tumor. LN involvement was significantly higher in patients with breast cancer who are carriers of CC genotype when compared with patients with breast cancer who are carriers of GG and GC genotypes $(p=0.01)$.

The result of PCR determination of IL- $10^{-1082} \mathrm{G} \rightarrow$ A genotypes in the studied groups revealed that, there was no significant difference in IL$10^{-1082} \mathrm{G} \rightarrow \mathrm{A}$ genotypes frequency (GG, GA and AA) in patients with breast cancer when compared with normal individuals $(\mathrm{p}=0.99)$ as shown in Table (4).

The Analysis of association between $\quad$ IL- $10^{1082} \mathrm{G} \rightarrow \mathrm{A}$ genotypes and clinicopathological features of breast cancer patients, shown in Table (5), revealed no association between $\mathrm{IL}-10^{1082} \mathrm{G} \rightarrow \mathrm{A}$ genotypes and ER expression, PR expression, LN 
involvement, and grade of the tumor. Increase in the tumor size was significantly higher in patients with breast cancer, who are carriers of AA genotype when compared with patients with breast cancer who are carriers of AG and GG genotypes ( $\mathrm{p}=$ $0.03)$.
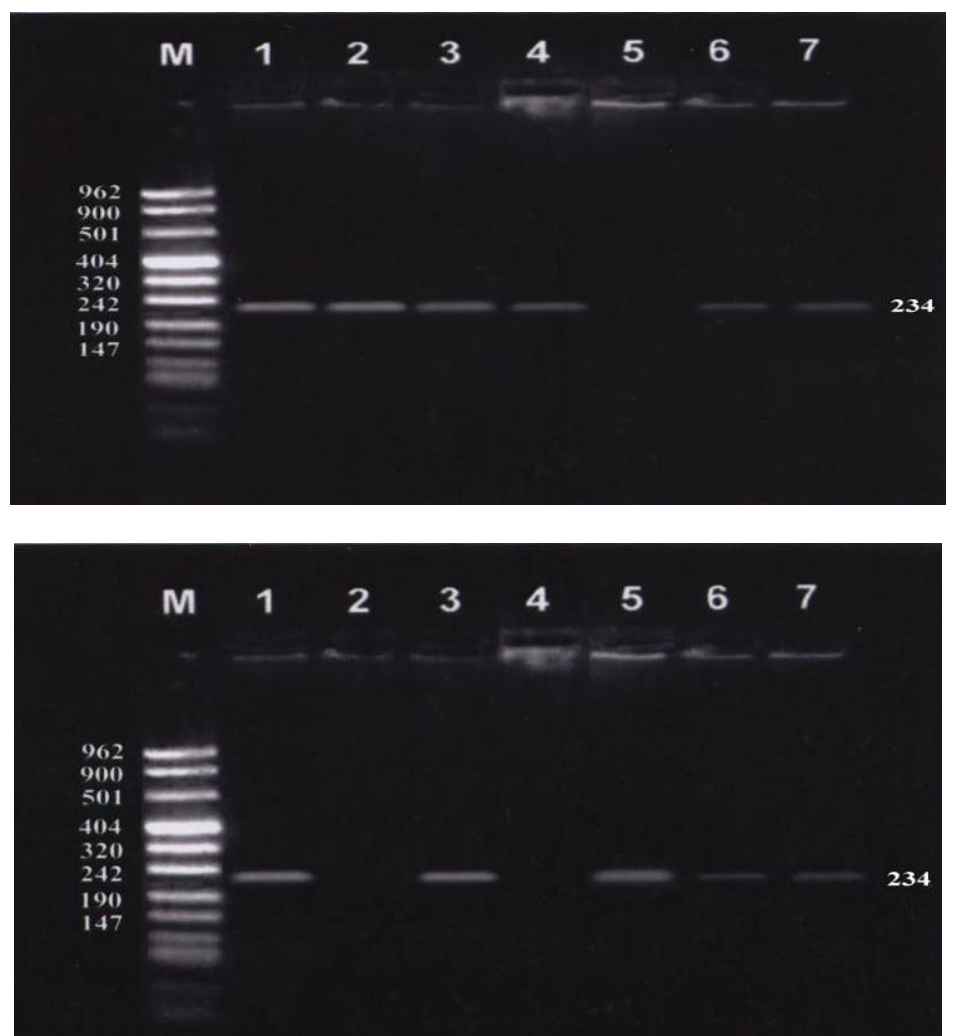

Figure (1): PCR amplification for IL-6 at $-174(\mathrm{G} \rightarrow \mathrm{C})$ polymorphisms using SSP for $\mathrm{G}$ allele (above) and $\mathrm{C}$ allele (below). lane M: DNA size marker, lanes 1, 3, 6, 7 (+ve for $\mathrm{G}$ and $\mathrm{C}$ giving $\mathrm{G} / \mathrm{C}$ genotype), lane 2, 4 (+ve for $\mathrm{G}$ and -ve for A giving $\mathrm{G} / \mathrm{G}$ genotype) and lanes 5 (+ve for $\mathrm{C}$ and -ve for $\mathrm{G}$ giving $\mathrm{C} / \mathrm{C}$ genotype), band size: $234 \mathrm{bp}$. 

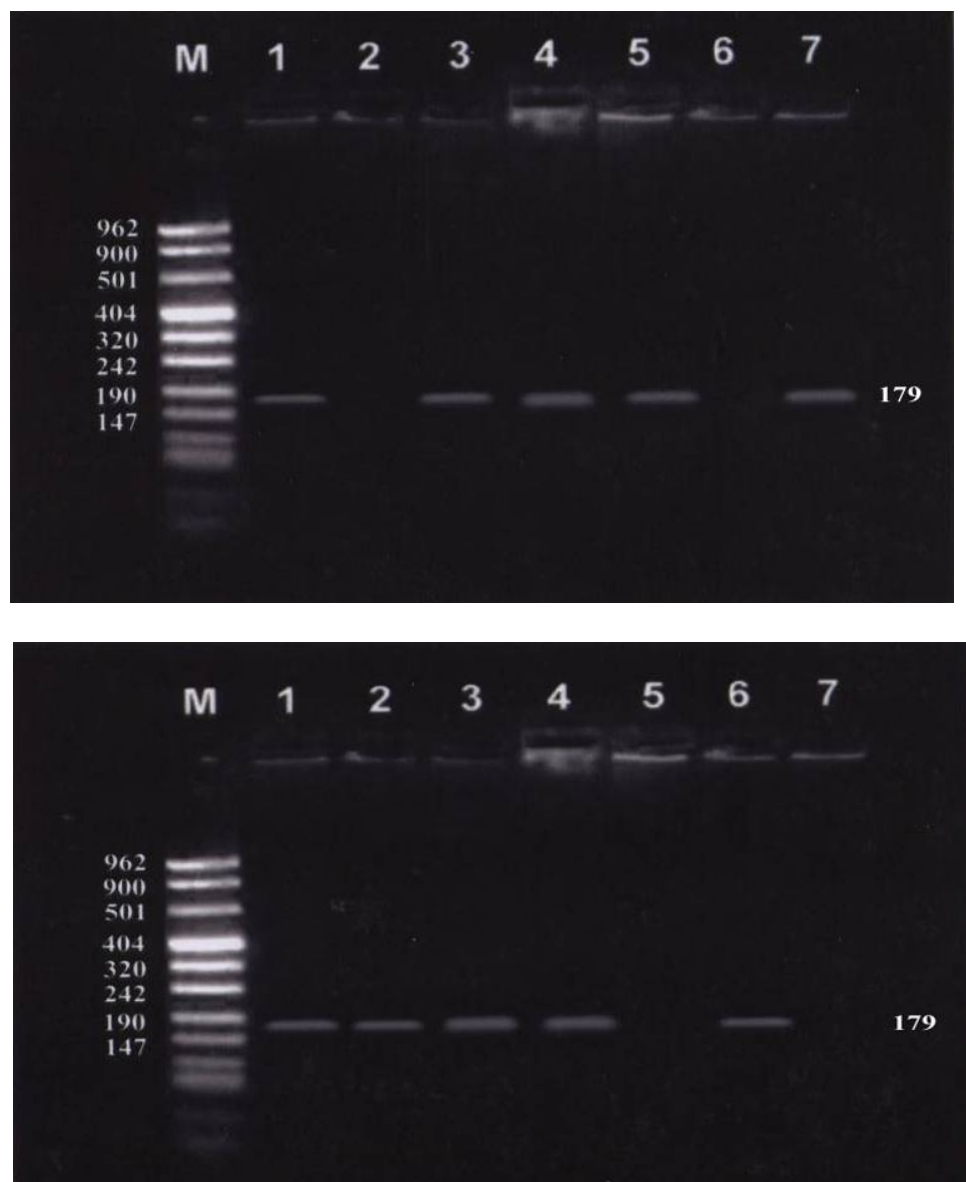

Figure (2): PCR amplification for IL-10 -1082(G $\rightarrow$ A) polymorphism using SSP for $\mathrm{G}$ allele (above) and A allele (below). Lane M: DNA size marker, lanes 1, 3, 4 (+ve for $\mathrm{G}$ and $\mathrm{A}$ giving $\mathrm{G} / \mathrm{A}$ genotype), lane 5, 7 (+ve for $\mathrm{G}$ and -ve for $\mathrm{A}$ giving $\mathrm{G} / \mathrm{G}$ genotype) and lanes 2, 6 (+ve for $\mathrm{A}$ and $-\mathrm{ve}$ for $\mathrm{G}$ giving $\mathrm{A} / \mathrm{A}$ genotype), band size:179 bp. 

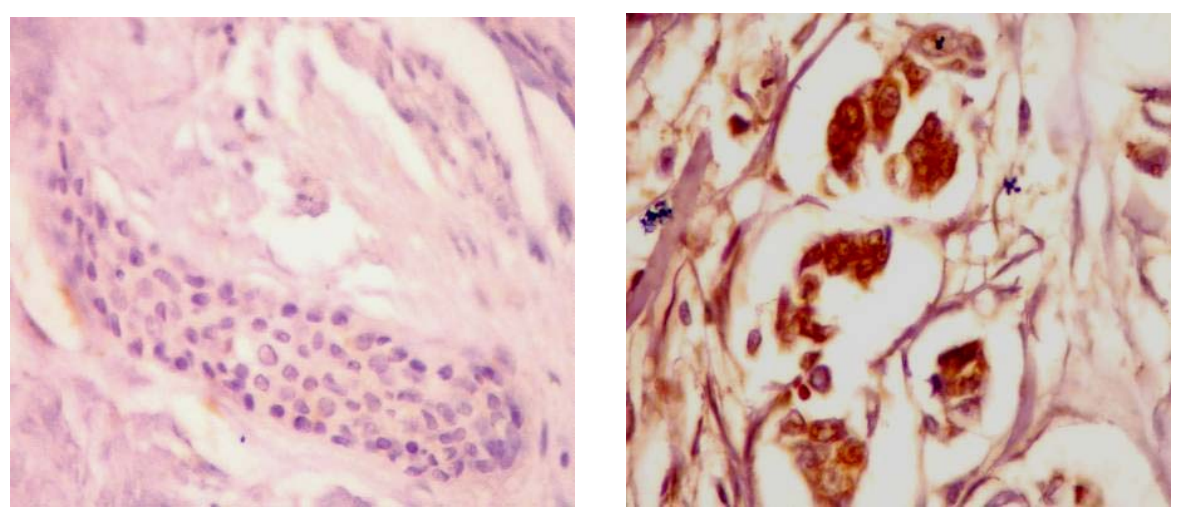

Figure (3): Immunohistochemical staining of breast tissue. Negative nuclear reaction (left) and positive nuclear reaction (right) for estrogen receptors in breast cancer cells $(400 \mathrm{X})$
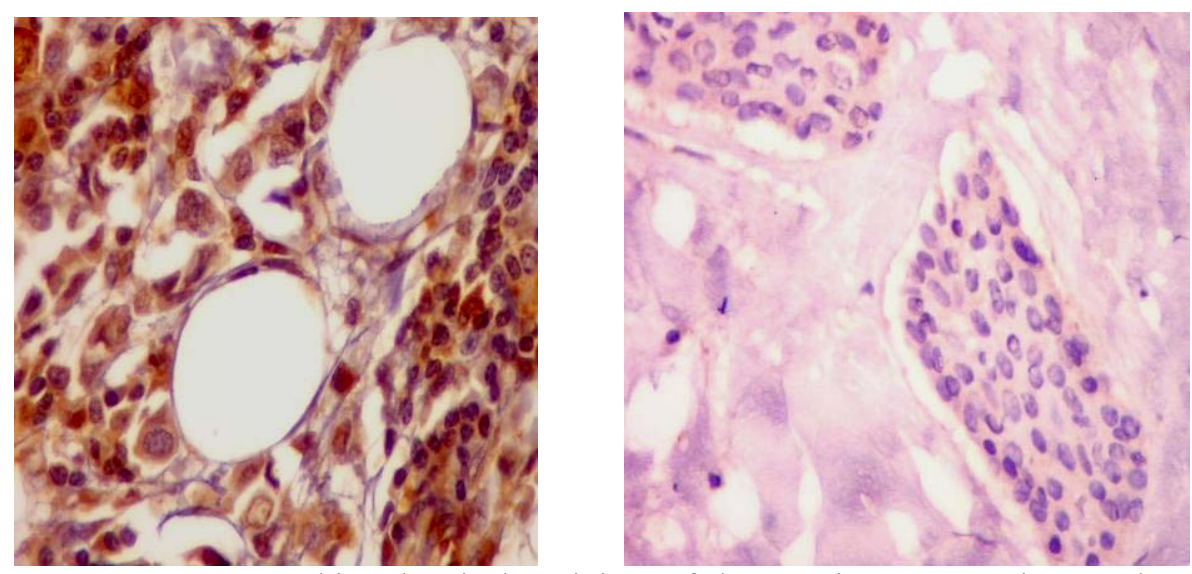

Figure (4): Immunohistochemical staining of breast tissue. Negative nuclear reaction (left) and positive nuclear reaction (right) for progesterone receptors in breast cancer cells (400X) 
Table (1): Clinical data of patients with breast cancer and healthy controls.

\begin{tabular}{|c|l|l|l|}
\hline Variable & $\begin{array}{l}\text { Patients, no. } \\
\text { (\%) } \\
\text { N=80 }\end{array}$ & $\begin{array}{l}\text { Control, no. } \\
\mathbf{( \% )} \\
\text { N=80 }\end{array}$ & P- value \\
\hline 1-Age of menarche & $12.3 \pm 2.1$ & $13.1 \pm 2.3$ & $\mathrm{P}=0.02$ \\
2-Menopausal status & $24(30 \%)$ & $27(33.75 \%)$ & $\mathrm{P}=0.73$ \\
a- Premenopausal. & $\mathrm{P}=0.83$ \\
b- Postmenopausal. & $56(70 \%)$ & $53(66.25 \%)$ & \\
3-ER expression. & $43(53.75 \%)$ & & \\
a- Positive & $37(26.25 \%)$ & & \\
b- Negative & $47(58.75 \%)$ & & \\
4-PR expression. & $33(31.25 \%)$ & & \\
a-Positive & $50(62.5 \%)$ & & \\
b-Negative & $30(37.5 \%)$ & & \\
5-LN involvement & & \\
a-Positive & $40(50 \%)$ & & \\
b-Negative & $26(32.5)$ & & \\
6-Tumor size & $14(17.5)$ & & \\
a- $<2$ cm & $30(37.5 \%)$ & & \\
b-2-5 cm & $43(53.75 \%)$ & & \\
c- $>$ 5cm & $7(8.75 \%)$ & & \\
7- Grade & & & \\
a- grade I & & \\
b- grade II & & \\
c- grade III & & \\
\hline
\end{tabular}

Table (2): Frequencies of IL-6 ${ }^{-174} G \rightarrow C$ genotypes and allelic polymorphisms among different studied groups.

\begin{tabular}{|l|l|l|l|}
\hline Genotypes & $\begin{array}{l}\text { Breast cancer } \\
\mathbf{N}=\mathbf{8 0}\end{array}$ & $\begin{array}{l}\text { Control } \\
\mathbf{N}=\mathbf{8 0}\end{array}$ & Significance \\
\hline GG & $24(30 \%)$ & $14(17.5 \%)$ & $\mathrm{P}=0.29$ \\
\hline GC & $46(57.5 \%)$ & $34(42.5 \%)$ & $\mathrm{P}=0.26$ \\
\hline CC & $10(12.5 \%)$ & $32(40 \%)$ & $\mathrm{P}=0.01$ \\
\hline G allele & $94(58.75 \%)$ & $62(38.75 \%)$ & $\mathrm{P}=0.01$ \\
\hline C allele & $66(41.25 \%)$ & $98(61.25 \%)$ & $\mathrm{P}=0.01$ \\
\hline
\end{tabular}


Table (3): Genotype Frequencies of $\mathrm{IL}^{-6^{-174}} \mathrm{G} \rightarrow \mathrm{C}$ and clinicopathological features of breast cancer patients.

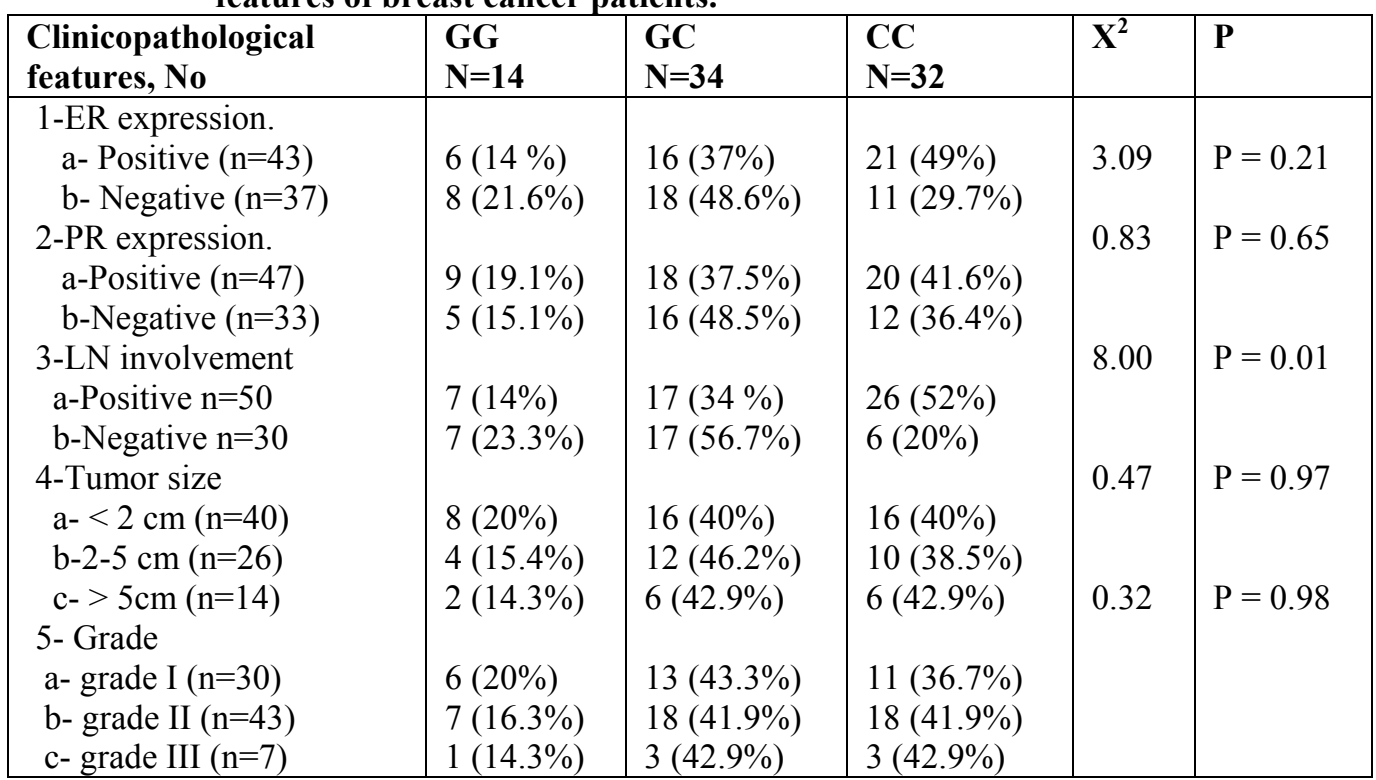

Table (4): Frequencies of $\mathrm{IL}-10^{1082} \mathrm{G} \rightarrow \mathrm{A}$ genotypes and allelic polymorphisms among different studied groups.

\begin{tabular}{|l|l|l|l|}
\hline & $\begin{array}{l}\text { Control } \\
\mathbf{N}=\mathbf{8 0}\end{array}$ & $\begin{array}{l}\text { Breast cancer } \\
\mathbf{N}=\mathbf{8 0}\end{array}$ & $\begin{array}{l}\text { Significance } \\
\mathbf{P} \text {-value }\end{array}$ \\
\hline GG & $16(20 \%)$ & $17(21.25 \%)$ & $\mathrm{P}=0.96$ \\
\hline GA & $50(62.5 \%)$ & $47(58.75 \%)$ & $\mathrm{P}=0.82$ \\
\hline AA & $14(17.5 \%)$ & $16(20 \%)$ & $\mathrm{P}=0.98$ \\
\hline G allele & $82(51.25 \%)$ & $81(50.6 \%)$ & $\mathrm{P}=0.93$ \\
\hline A allele & $78(48.75 \%)$ & $79(49.4 \%)$ & $\mathrm{P}=0.93$ \\
\hline
\end{tabular}


Table (5): Genotype frequencies of $\mathrm{IL}-10^{1082} \mathrm{G} \rightarrow \mathrm{A}$ and clinicopathological features of breast cancer patients.

\begin{tabular}{|c|c|c|c|c|c|}
\hline $\begin{array}{l}\text { Clinicopathological } \\
\text { features, }(\text { No }=80)\end{array}$ & $\begin{array}{l}\text { GG } \\
\text { N=17 }\end{array}$ & $\begin{array}{l}\text { GA } \\
\mathbf{N}=47\end{array}$ & $\begin{array}{l}\mathrm{AA} \\
\mathrm{N}=16\end{array}$ & $\overline{X^{2}}$ & $\mathbf{P}$ \\
\hline $\begin{array}{l}\text { 1-ER expression. } \\
\text { a- Positive }(n=43)\end{array}$ & $9(21 \%)$ & $25(56 \%)$ & $9(21 \%)$ & 005 & $P=0.97$ \\
\hline b- Negative $(n=37)$ & $8(21.6 \%)$ & $22(59.5 \%)$ & $7(19 \%)$ & & $P=0.91$ \\
\hline 2-PR expression. & & & & 1.5 & $P=0.47$ \\
\hline a-Positive $(\mathrm{n}=47)$ & $8(17 \%)$ & $30(63.8 \%)$ & $9(19.1 \%)$ & & \\
\hline b-Negative $(n=33)$ & $9(27.3 \%)$ & $17(51.5 \%)$ & $7(21.2 \%)$ & 0.47 & $P=0.78$ \\
\hline $\begin{array}{l}\text { 3-LN involvement } \\
\text { a-Positive }(\mathrm{n}=50) \\
\text { b-Negative }(\mathrm{n}=30)\end{array}$ & $\begin{array}{l}11(22 \%) \\
6(20 \%)\end{array}$ & $\begin{array}{l}28(56 \%) \\
19(63.3 \%)\end{array}$ & $\begin{array}{l}11(22 \%) \\
5(16.7 \%)\end{array}$ & 10.2 & $\mathrm{P}=0.03$ \\
\hline 4-Tumor size & & & & & \\
\hline $\mathrm{a}-<2 \mathrm{~cm}(\mathrm{n}=40)$ & $3(7.5 \%)$ & $26(65 \%)$ & $11(27.5 \%)$ & 1.42 & $\mathrm{P}=0.84$ \\
\hline $\mathrm{b}-2-5 \mathrm{~cm}(\mathrm{n}=26)$ & $9(34.6 \%)$ & $13(50 \%)$ & $4(15.4 \%)$ & & \\
\hline $\mathrm{c}->5 \mathrm{~cm}(\mathrm{n}=14)$ & $5(35.7 \%)$ & $8(57.1 \%)$ & $1(7.1 \%)$ & & \\
\hline 5- Grade & & & & & \\
\hline a- grade $I(n=30)$ & $5(16.7 \%)$ & $18(60 \%)$ & $7(23.3 \%)$ & & \\
\hline b- grade II $(n=43)$ & $11(25.6 \%)$ & $24(55.8 \%)$ & $8(18.6 \%)$ & & \\
\hline $\mathrm{c}$ - grade III $(\mathrm{n}=7)$ & $1(14.3 \%)$ & $5(71.4 \%)$ & $1(14.3 \%)$ & & \\
\hline
\end{tabular}

\section{DISCUSSION}

As prophylactic interventions in order to reduce breast cancer risk have gained rising popularity, the clinical importance of breast cancer risk assessment has increased dramatically $^{\mathbf{2 2 , 2 3}}$. Testing of mutations and polymorphisms in candidate genes of breast cancer has been proposed as a powerful tool in assessing an unaffected woman's personal risk for disease ${ }^{\mathbf{2 4 - 2 6}}$.

Although numerous genetic association studies dealing with breast cancer have been published, few candidate genes for this disease have been established. Cytokines in general are thought to be involved in numerous physiologic and pathologic conditions. Among cytokines, IL-6 probably seems to play the most important role in breast carcinogenesis ${ }^{6,7}$.

A proinflammatory multifunctional interleukin-6 is a key cytokine in the humoral immune response involving the activation of B cells ${ }^{27}$. The -174G/CIL-6 polymorphism has been reported to influence plasma concentrations of the corresponding cytokine in response to different inflammatory stimuli. In this connection it has been studied for associations with many inflammatory and neoplastic diseases. Several investigators observed significant racial, ethnical and populational difference in the frequencies of the $-174 \mathrm{G} / \mathrm{C}$-alleles, 
underlying the importance of a local reference population when evaluating the clinical relevance of this polymorphism ${ }^{28}$. To the best of our knowledge, this is a first report on the IL-6 $-174 \mathrm{G} / \mathrm{C}$ polymorphism in the Egyptian population.

With respect to the $-174 \mathrm{G} / \mathrm{C}$ IL6 polymorphism, this study provides data with respect to a significant association between the IL6 polymorphism CC genotype, $\mathrm{C}$ allele, and breast cancer.

As previously published for other malignancies ${ }^{29}$, the $-174 \mathrm{G} / \mathrm{C}$ IL6 polymorphism likely is important for carcinogenesis. The 174 G/C IL6 polymorphism is known to reduce gene transcription rate subsequently reducing protein levels. IL-6 is known to inhibit tumor cell growth. Therefore, women with decreased protein expression are at an increased risk for developing breast cancer.

The results of this study are in accordance with ${ }^{30}$, who found an association of the -174 G/C IL6 polymorphism with breast cancer susceptibility in Caucasian females. In that study, the carriers of the $\mathrm{C}$ allele had an increased risk for breast cancer in an allele dose-dependent fashion. Also, Iacopetta et al., ${ }^{12}$ showed that the IL6 polymorphism was predictive of an aggressive breast cancer phenotype. However, Balasubramanian et al., ${ }^{31}$ showed that the IL6 -174G/C polymorphism was not associated with either breast cancer risk or severity and prognosis.

Litovkin et al., ${ }^{28}$ failed to find such association of the -174 G/C IL6 polymorphism with breast cancer susceptibility in the Ukrainian population. Their observations support the suggestion that the $174 \mathrm{G} / \mathrm{C}$ polymorphism in the IL-6 gene is not a risk factor of major importance for breast cancer, although it may possibly affect to some extent the severity of the disease. The presence of the -174 G/C IL6 polymorphism increases the risk of breast cancer in a dose dependent fashion.

We also, found that patients carrying IL6 -174 CC genotype were correlated with higher LN involvement $(p=0.01)$ of breast cancer at the time of diagnosis compared with others. The findings suggest that the IL6 -174CC genotype might be adverse prognostic factors in breast cancer in Egyptian women. However, the study from the European Caucasian women showed that the homozygosity for the $-174 \mathrm{C}$ allele was significantly associated with poor histological grade and with ductal histology, and association with larger tumor size and low estrogen receptor content ${ }^{12}$.

This case-control study evaluated the association between the polymorphisms of the IL-10 promoter and breast cancer in Egyptian population. The data did not show significant differences in allele and genotypes frequencies of IL-10 $-1082(\mathrm{G} \rightarrow \mathrm{A})$ polymorphism between breast cancer patients and healthy controls. In concordance with this study, many authors ${ }^{2,30-32}$, reported that there were no apparent relationship of the IL-10 gene promoter polymorphisms with the risk of breast cancer. However, these results are not consistent with the study from the Italian population 
showed that the IL-10 -1082AA genotype was correlated with a marked increase in breast cancer risk $^{34}$. Although it is difficult to determine the reasons behind the contradictory results in these studies, the different genetic background of study population may be one of the main factors.

We also, found that patients carrying IL-10 -1082AA were correlated with increased tumor size only, but not LN involvement and higher tumor stage of breast cancer at the time of diagnosis. However, the study from the Chinese Han women showed that the IL-10 -1082AA genotype was correlated with higher LN involvement and higher tumor stage of breast cancer ${ }^{32}$ which may be due to different populations.

$\begin{array}{lr}\text { IL-10 is a multifunctional } \\ \text { cytokine } \\ \text { immunosuppressive } & \text { with }\end{array}$
antiangiogenic functions, which may play varied roles in the pathogenesis and development of breast cancer. Although the genetic control of IL-10 expression is not clearly understood yet, polymorphisms in promoter have been reported to determine interindividual differences in IL-10 production $^{17,35}$.

CONCLUSION:

The homozygous CC genotype of the IL$6-174 \mathrm{G} \rightarrow \mathrm{C}$, but not IL-10 $1082(\mathrm{G} \rightarrow \mathrm{A}) \quad$ genotype was associated with breast cancer in Egyptian women. Also, IL6 -174 CC genotype was correlated with LN involvement in patients with breast cancer and IL-10 -1082AA genotype was correlated with increased tumor size in patients with breast cancer.

\section{REFFERENCES}

1. Kamangar F, Dores GM, Anderson WF(2006): Patterns of cancer incidence, mortality, and prevalence across five continents: defining priorities to reduce cancer disparities in different geographic regions of the world. J. Clin. Oncol., 24 (14): 2137-50.

2. Smyth MJ, Cretney E, Kershaw MH, Hayakawa Y. (2004):.Cytokines in cancer immunity and immunotherapy. Immunol. Rev., 202: 275-93.

3. Dichl $S$ and Rincon M. (2002):. The two faces of IL-6 onTh1/Th2 differentiation. Mol. Immunol., 39: 531-6.

4. Asgeirsson KS, Olafsdottir K, Jonasson JG, Ogmundsdottir HM. (1998): The effects of IL-6 on cell adhesion and e-cadherin expression in breast cancer. Cytokine 10:720-8.

5. Badache A, Hynes NE. (2001):.Interleukin 6 inhibits proliferation and, in cooperation with an epidermal growth factor receptor autocrine loop, increases migration of T47D breast cancer cells. Cancer Res., 61: 383-91.

6. Danforth DN, Sgagias MK. (1993):- Interleukin-1 $\alpha$ andinterleukin-6 act additively to inhibit growth of MCF-7 breast cancer cells in vitro. Cancer Res., 53: 1538-45.

7. Robinson EK, Sneige N, Grimm EA. (1998): Correlation of interleukin 6 with interleukin 1ain human mammary tumors, but not with estrogen receptor expression. Cytokine 10: 970-6. 
8. Bozcuk H, Uslu G, Samur M, Yildiz M, Ozben T, Ozdoğan M, et al. (2004):. Tumor necrosis factor- $\alpha$, interleukin- 6 , and fasting serum insulin correlate with clinical outcome in metastatic breast cancer patients treated with chemotherapy. Cytokine 27:58-65.

9. Bowcock AM, Kidd JR, Lathrop GM, Daneshvar L, May LT, Ray A, et al. (1988): The human "interferonbeta 2/hepatocyte stimulating factor/interleukin-6" gene: DNA polymorphism studies and localization to chromosome $7 \mathrm{p} 21$. Genomics 3: 8-16.

10. MA, Green FR, Terry C, Mayosi BM, Julier C, Lathrop M, et al. (2002):. Genotype at a promoter polymorphism of the interleukin-6 gene is associated with baseline levels of plasma Creactive protein. Cardiovasc. Res., 53: 1029-34.

11. DeMichele A, Martin AM, Mick R, Gor P, Wray L, KleinCabral M, et al. (2003):.Interleukin-6_174 G/C polymorphism is associated with improved outcome in high-risk breast cancer. Cancer Res., 63: 8051-6.

12. Iacopetta B, Grieu F, Joseph D. (2004):.he_174 G/C gene polymorphism in interleukin-6 is associated with an aggressive breast cancer phenotype. Br. J. Cancer 90: 419- 22.

13. Mocellin S, Marincola F, Rossi CR, Nitti D, Lise M. (2004): The multifaceted relationship between IL-10 and adaptive immunity: putting together the pieces of a puzzle. Cytokine Growth Factor Rev., 15:61-76.

14. Gibson AW, Edberg JC, Wu J, Westendorp RG, Huizinga TW, Kimberly RP. (2001): Novel single nucleotide polymorphisms in the distal IL-10 promoter affect IL-10 production and enhance the risk of systemic lupus erythematosus. J. Immunol., 166:3915-22.

15. Mocellin S, Marincola FM, Young HA (2005):. Interleukin10 and the immune response against cancer: a counterpoint. J. Leukoc. Biol., 78:1043-51.

16. Matsuda M, Salazar F, Petersson M, Masucci G, Hansson J, Pisa P. (1994): Interleukin 10 pretreatment protects target cells from tumorand allospecific cytotoxic $\mathrm{T}$ cells and downregulates HLA class I expression. J. Exp. Med., 180:2371-76.

17. Eskdale J, Kube D, Tesch $H$. (1997):.Mapping of the human IL10 gene and further characterization of the 5'flanking sequence. Immunogenetics 46:120-8.

18. Howell WM, Rose-Zerilli MJ. (2007): Cytokine gene polymorphisms, cancer susceptibility and prognosis. J. Nutr., 137(1 Suppl.) :194S-9S.

19. Cavet J, Dickinson AM, Norden J, Taylor P, Jackson G, Middleton P. (2001): Interferon- $\gamma$ and interleukin-6 gene polymorphisms associate with graft-versus-host disease in HLA-matched sibling bone marrow transplantation. Blood 98 (5) $1594-600$ 
20. Cavet J, Middleton $P$, Segall $\mathrm{M}$, Noreen $\mathrm{H}$, Davies $\mathrm{S}$, Dickinson AM. (1999): Recipient Tumor Necrosis Factoralpha and Interleukin-10 Gene Polymorphisms Associate With Early Mortality and Acute GraftVersus-Host Disease Severity in HLA-Matched Sibling Bone Marrow Transplants. Blood94 (11): 3941-46

21. Kiernan J. (1999):.Histological and histochemical methods: theory and practice. 1999, 3rd ed. Oxford: Butterworth-Heinemann

22. Fisher B, Costantino JP, Wickerham DL, Redmond CK, Kavanah M, Cronin WM, et al. (1998): Tamoxifen for prevention of breast cancer: report of the National Surgical Adjuvant Breast and Bowel Project P-1 Study. J. Natl. Cancer Inst., 90: $1371-88$.

23. PowlesT, Eeles R, Ashley S, Easton D, Chang J, Dowsett $M$, et al. (1998): Interim analysis of the incidence of breast cancer in the Royal Marsden Hospital Tamoxifen Randomized Chemoprevention Trial. Lancet352:98-101.

24. Huang CS, Chern HD, Chang KJ, Cheng CW, Hsu SM, Shen CY. (1999): Breast cancer risk associated with genotype polymorphism of the estrogen metabolizing genes CYP17, CYP1A1, and COMT: a multigenic study on cancer susceptibility. Cancer Res., 59: 4870-5.

25. Hefler LA, Tempfer CB, Grimm C, Lebrecht A, Ulbrich E, Heinze $G$, et al.
(2004): Estrogen metabolizing gene polymorphisms in the assessment of breast carcinoma risk and fibroadenoma risk in Caucasian women. Cancer 101: 264-9.

26. Kammerer S, Roth RB, Reneland R, Marnellos G, Hoyal CR, Markward NJ, et al. (2004): Large-scale association study identifies ICAM gene region as breast and prostate cancer susceptibility locus. Cancer Res., 64:8906-10.

27. Smith KC, Bateman AC, Fussell HM, Howell WM. (2004): Cytokine gene polymorphisms and breast cancer susceptibility and prognosis. Eur. J. Immunogenet., 31:167-73.

28. Litovkin KV., Domenyuk VP, Bubnov VV, Zaporozhan VN. (2007): Interleukin-6 -174g/C Polymorphism In Breast Cancer And Uterine Leiomyoma Patients: A Population-Based Case Control Study. Experimental Oncology 29: 295-8.

29. Landi S, Moreno V, GioiaPatricola L, Guino E, Navarro M, de Oca J, et al. (2003):. Association of common polymorphisms in inflammatory genes interleukin (IL)6, IL8, tumor necrosis factor- $\alpha$, NFK $\mathrm{B} 1$, and peroxisome proliferatoractivated receptor gamma with colorectal cancer. Cancer Res., 63: 3560- 6

30. Hefler LA, Grimm C, Lantzsch T, Lampe D, Leodolter S, Koelbl H, et al. (2005): Interleukin-1 and 
interleukin-6 gene polymorphisms and the risk of breast cancer in Caucasian women. Clin. Cancer Res., 11(16):5718-21

31. Balasubramanian SP, Azmy IA, Higham SE. (2006): Interleukin gene polymorphisms and breast cancer: a case control study and systematic literature review. BMC Cancer 6:188.

32. Kong F, Liu J, Liu Y, Song B, Wang H2, Liu W. (2010): Association of interleukin-10 gene polymorphisms with breast cancer in a Chinese population. J. Exp. Clin. Cancer Res., 29:72.

33. Howell WM, Rose-Zerilli MJ. (2006): Interleukin- 10 polymorphisms, cancer susceptibility and prognosis. Fam. Cancer 5(2):143-9.

34. Giordani L, Bruzzi $P$, Lasalandra C, Quaranta $M$, Schittulli F, Della F, et al. (2003): Polymorphisms of Interleukin-10 and tumor necrosis factor- $\alpha$ gene promoter and breast cancer risk. Clin. Chem., 49:1664-7.

35. Turner- DM, Williams DM, Sankaran D, Lazzarus M, Sinnott PJ, Hutchinson IV. (1997): An investigation of polymorphism in the interleukin10 gene promoter. Eur. J. Immunogenet., 24:1-8. 


$$
\begin{aligned}
& \text { إرتباط الأثكال المتعددة لجينات IL-6 و IL-10 بسرطان الثذى } \\
& \text { في النساء المصريات }
\end{aligned}
$$

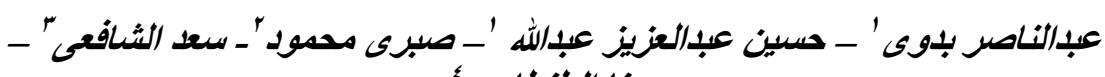

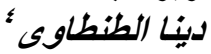

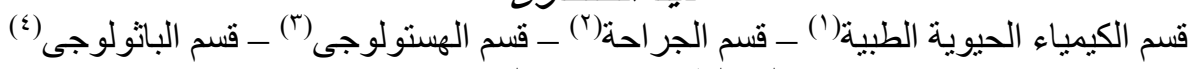

$$
\begin{aligned}
& \text { كلية الطب - جامعة المنصورة }
\end{aligned}
$$

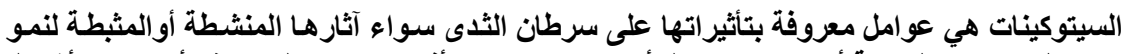

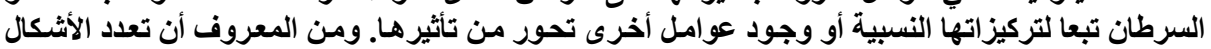

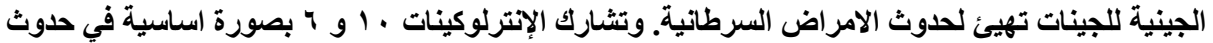

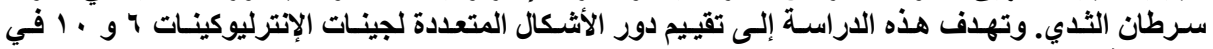

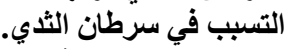

وقات شملت هذه الثراسة على ثمانون حالة من الإنـاث المصابات بسرطان الثدي و ثمـانون حالحة أخرى

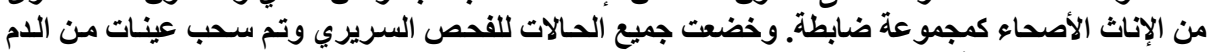
من جميع الحالات في أنابيب تحتوي على EDTA بوصفها مضادة للتخثر لتحليل جينات الإنترليوكينات بو و لو

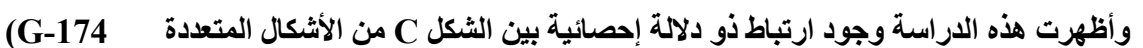

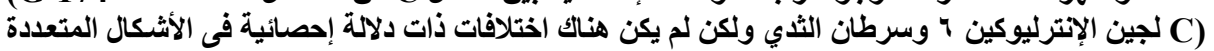

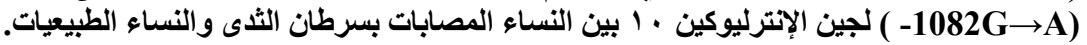

